\title{
MEMBUDAYAKAN KEBIASAAN MENCUCI TANGAN \\ ( STUDI KASUS PENANGANAN MASALAH KECACINGAN PADA ANAK DI DUSUN MANYULUH, DESA LAHEI, KECAMATAN MENTANGAI, KABUPATEN KAPUAS, \\ PROVINSI KALIMANTAN TENGAH )
}

\section{ASTRID TERESA}

\section{Pendahuluan}

Indonesia merupakan salah satu negara yang berkembang, tetapi di Indonesia sendiri masih banyak penyakit yang menjadi masalah kesehatan, salah satu di antarnya ialah cacing perut yang ditularkan melalui tanah. Kecacingan ini dapat mengakibatkan menurunnya kondisi kesehatan gizi, kecerdasan dan produktivitas penderitanya, sehingga secara ekonomi banyak menyebabkan kerugian serta mempengaruhi kualitas sumber daya manusia. Prevalensi kecacingan di Indonesia pada umumnya masih sangat tinggi, terutama pada golongan penduduk yang kurang mampu mempunyai resiko tinggi terjangkit penyakit ini. (Surat Keputusan Menteri Kesehatan No. 424/MENKES/SK/V/2006:3).

Data WHO menyebutkan lebih dari 1 miliar penduduk dunia menderita kecacingan. Di indonesia, sekitar 40-60\% penduduk Indonesia menderita kecacingan. Kecacingan bukan hanya penyakit yang bisa terjangkit pada anak-anak, tapi juga pada orang dewasa. Biasanya seorang siswa yang terinfeksi cacing akan mengalami kekurangan hemoglobin (Hb) hingga 12 g\% dan akan berdampak terhadap kemampuan darah membawa oksigen ke berbagai jaringan tubuh termasuk ke otak, akibatnya penderita kecacingan mengalami penurunan daya tahan tubuh serta metabolisme jaringan otak. Bahkan, dalam jangka panjang, penderita akan mengalami kelemahan fisik dan intelektualitas. (www.depkes.go.id diakses tanggal 27 April 2012).

Selama ini upaya pencegahan dan pengobatan telah dilakukan oleh pemerintah melalui dinas kesehatan di kegiatan-kegiatan pokok Puskesmas, tetapi masih belum maksimal karena dilihat dari data Profil Kesehatan Indonesia 2008 (ditjen PP-PL, Departemen Kesehatan RI, 2009) Prevalensi Nasional Kecacingan adalah Banten 60,7\%, NAD 59,2\%, NTT 27,7\%, Kalbar 26,2\%, Sumbar 10,1\%, Jabar 6,7\%, Sulut 6,7\%, Kalteng 5,6\%.

Berdasarkan data Profil Kesehatan Indonesia 2008 tersebut tampak bahwa problem kecacingan pada anak masih memerlukan perhatian, khususnya bagi provinsi Kalimantan Tengah yang berada pada urutan ke delapan.

Data tersebut perlu dibuktikan apakah anak-anak di Dusun Manyuluh juga mengalami masalah serupa sehingga perlu dilaksanakan penyuluhan tentang cacing serta pengobatannya dan pencegahan dengan cara mencuci tangandalam rangka peningkatan upaya peningkatan kualitas hidup masyarakat.

Menurut Profil Lokasi Kegiatan Program BioRight-PREKT Dusun Manyuluh, merupakan salah satu dusun yang menjadi wilayah administrasi Desa Lahei, Kecamatan Mantangai, Kabupaten Kapuas, Provinsi Kalimantan Tengah. Luas wilayah Desa Tanjung Taruna $\pm 33 \mathrm{~km}^{2}$ atau 0,22\% dari luas wilayah Kabupaten Pulang Pisau atau sekitar 0,54\% dari luas Kecamatan Mantangai.

Dusun Manyuluh berada diantara jalur Sungai Mangkutub dan Sungai Muroi yang merupakan anak sungai (DAS) Kapuas.

Jumlah penduduk di Dusun Manyuluh, Kabupaten Kapuas sebanyak \pm 244 jiwa, yang terdiri dari penduduk laki-laki sebanyak 128 jiwa dan penduduk perempuan sebanyak 96 jiwa. Sedangkan jumlah Kepala Keluarga (KK) di Dusun Manyuluh sebanyak 56 KK, dengan tingkat kepadatan penduduk Dusun Manyuluh sekitar 8 jiwa $/ \mathrm{km}^{2}$. 
Keadaan pendidikan penduduk di Dusun Manyuluh dapat dikatakan masih rendah. Hampir 90\% penduduk Dusun Mayuluh hanya tamat SD, dan bahkan terdapat beberapa penduduk dewasa yang tidak sekolah dan buta huruf. Pendidikan tertinggi penduduk Dusun Manyuluh hanya tamat SMP yaitu sekitar 0,5\%. Sedangkan yang berpendidikan SMA dan berpendidikan tinggi tidak ada.

Permukiman masyarakat masih terkonsentrasi atau tidak jauh dari bantaran sungai. Terdapat beberapa rumah masyarakat di bagian atas/daratan, namun masih tampak terpencarpencar. masyarakat memanfaatkan sungai selain untuk transportasi, juga untuk mendirikan jamban tempat mencuci, mandi, kakus (MCK).

Ketersediaan berbagai sarana atau fasilitas layanan kesehatan bagi masyarakat di Dusun Manyuluh masih belum ada. Selain sarana/fasilitas kesehatan yang belum ada, berbagai program ataupun layanan kesehatan baik oleh pemerintah desa/ kecamatan/kabupaten yang masuk ke Dusun Manyuluh hingga sekarang juga tidak pernah ada.

\section{Metode Kegiatan}

Kegiatan ini bertujuan untuk menambah pengetahuan anak tentang perilaku hidup bersih dan sehat, cara mencuci tangan yang benar sehingga dapat menurunkan prevalensi kecacingan anak di Dusun Manyuluh.

Solusi yang ditawarkan adalah memberikan pelatihan anak tentang cara mencuci tangan yang benar dan memberikan pengobatan kepada anak yang menderita kecacingan.

Metode yang dilakukan dalam kegiatan ini, adalah sebagai berikut :

1. Penyuluhan kesehatan tentang pentingnya perilaku hidup bersih dan sehat

2. Penyuluhan kesehatan dan demo tentang cara mencuci tangan dengan benar

3. Pelayanan kesehatan berupa :

a. Pemeriksaan kesehatan terhadap anak-anak di Dusun Manyuluh, meliputi

penimbangan berat badan, pengukuran tinggi badan dan pemeriksaan fisik.

b. Pengobatan terhadap anak-anak di Dusun Manyuluh

c. Mencatat semua hasil pemeriksaan dalam rekam medik

4. Memberikan vitamin penambah nafsu makan dan penambah darah

5. Melakukan wawancara untuk pengisian kuesioner

6. Melaporkan dan mempresentasikan hasil penyuluhan

7. Mengevaluasi hasil pengabdian agar diketahui manfaat dan kekurangan dari pelaksaan kegiatan.

\section{Hasil dan Pembahasan}

- Jumlah anak yang mengikuti pelatihan 46 orang

\begin{tabular}{|c|c|c|c|c|}
\hline \multirow{2}{*}{ NO } & \multirow{2}{*}{ JUMLAH USIA } & \multicolumn{2}{|c|}{ JUMLAH JIWA } & \multirow{2}{*}{ JUMLAH } \\
\cline { 3 - 4 } & & LAKI - LAKI & PEREMPUAN & \\
\hline $\mathbf{1}$ & $\mathbf{2}$ & $\mathbf{3}$ & $\mathbf{4}$ & $\mathbf{5}$ \\
\hline 1 & $2-5$ tahun & 5 & 11 & 16 \\
\hline 2 & $6-9$ tahun & 4 & 9 & 13 \\
\hline 3 & $10-12$ tahun & 9 & 8 & 17 \\
\hline
\end{tabular}

1. Terbentuknya kesadaran anak dalam perilaku hidup bersih dan sehat

2. Peningkatan pengetahuan anak tentang cara cuci tangan yang benar

3. Mendapatkan data kesehatan yang terbaru terutama data kecacingan pada anak-anak di Dusun Manyuluh 
4. Memberikan vitamin penambah nafsu makan dan vitamin penambah darah kepada 46 anak

Menurut DEPKES 2007, mencuci tangan adalah proses yang secara mekanis melepaskan kotoran dan debris dari kulit tangan dengan menggunakan sabun dan air. Mencuci tangan dengan sabun merupakan salah satu tindakan sanitasi dengan membersihkan tangan dan jari jemari menggunakan air dan sabun sehingga menjadi bersih dan dapat memutuskan mata rantai kuman penyakit.

Idealnya mencuci tangan sebaiknya menggunakan air bersih, air mengalir dan sabun. Air bersih adalah air yang jernih, tidak berbau dan tidak berwarna. Sedangkan sabun dapat membantu proses pelepasan kotoran dan kuman yang menempel di permukaan luar kulit tangan dan kuku secara kimiawi. Dengan menggunakan air yang mengalir maka kotoran dan kuman akan luruh terbawa air.

Cacingan merupakan salah satu masalah utama kesehatan anak di Indonesia. Sanitasi yang buruk dan masih kurangnya kesadaran pola hidup bersih merupakan penyebab utama tingginya jumlah penderita penyakit ini. Seseorang dikatakan menderita cacingan apabila didalam tubuhnya (perutnya) terdapat cacing. Cacing di dalam perut ini bisa keluar dari mulut, hidung atau saat buang air besar dan jika dilakukan pemeriksaan pada tinjanya terdapat telur cacing.

Walaupun tidak menyebabkan kematian, penyakit cacingan perlu ditangani dengan serius karena dapat mengakibatkan menurunnya daya tahan tubuh terhadap penyakit dan terhambatnya tumbuh kembang anak, karena cacing mengambil nutrisi yang penting bagi tubuh, misalnya protein, karbohidrat dan zat besi.

\section{Empat jenis cacing yang paling umum menginfeksi manusia : \\ 1. Cacing Gelang (Ascaris Lumbricoides)}

Cacing gelang adalah cacing yang paling umum menginfeksi manusia. Cara penularannya melalui makanan dan minuman yang terkontaminasi telurnya. Dalam usus halus, telur akan menetes dan keluar larva yang dapat menembus usus, mengikuti aliran darah menuju jantung kanan lalu ke paru. Larva dapat merangsang laring sehingga terjadi batuk dan dapat masuk ke dalam saluran cerna melalui kerongkongan. Larva menjadi cacing dewasa di dalam usus halus, dan dalam usia 2 bulan akan bertelur. Dalam sehari seekor cacing gelang betina dapat bertelur hingga 200.000 telur, yang kemudian dibuang ke dalam tinja dan menetas di dalam tanah, parah akan menimbulkan gejala gangguan gastrointestinal, kurang gizi, perut buncit dan lesu/ kurang semangat.

\section{Cacing kremi (Enterobius vermicularis)}

Cara penularannya melalui tangan yang memegang benda seperti baju, kasur, bantal, mainan, uang, peralatan makan, peralatan mandi/toilet, dll yang telah tercemar telur cacing kremi. Kemudian telur cacing yang menempel di tangan tersebut masuk ke dalam tubuh ketika orang tadi memasukan tangannya ke mulut. Telur cacing lalu menetas dalam usus kecil, bergerak turun ke usus besar dan melekat disana sampai menjadi dewasa. Cacing dewasa lalu bergerak ke sekitar dubur dan bertelur, telur ini dapat bertahan hidup selama tiga minggu. Saat itulah penderita akan mulai merasakan gatal-gatal di sekitar anus yang biasanya lebih intens di malam hari, sehingga menyebabkan gelisah dan sukar tidur, ini merupakan gejala khas infeksi cacing kremi. Anus/ dubur yang gatal mendorong penderita untuk menggaruknya, garukan tangan pada anus membawa telur cacing ini menyebar ke benda- benda disekitarnya, dan jika telur ini termakan, terulanglah siklus ini. Cacing kremi mudah sekali menular dan jika seseorang terkena, seluruh keluarga perlu diobati. Saat pengobatan, 
sprei, sarung bantal dan pakaian yang dipakai perlu dicuci. Dibutuhkan waktu sekitar satu bulan dari menelan telur cacing sampai merasakan gatal-gatal di anus.

\section{Cacing tambang (Ancylostoma duodenale dan Necator americanus)}

Di Indonesia penderita infeksi cacing tambang tinggi di daerah pedesaan, terutama perkebunan. Infeksi cacing ini disebabkan oleh kebiasaan masyarakat desa yang buang air besar di tanah dan pemakaian feces sebagai pupuk. Cara penularannya melalui larva cacing yang ada di tanah masuk ke kaki manusia yang tidak menggunakan alas kaki dan menembus kulit kaki lalu masuk ke paru-paru melalui sirkulasi darah. Larva kemudian bergerak ke saluran udara menuju tenggorokan dan tertelan lalu menuju ke usus kecil, melekat pada dinding usus dan berkembang menjadi cacing dewasa. Cacing dewasa ini akan dinding usus dan berkembang menjadi cacing dewasa. Cacing dewasa ini akan menghisap darah dari dinding usus sehingga menyebabkan perdarahan di usus yang ditempati.

Saat usia lima bulan cacing betina mulai bertelur, telur ini akan dikeluarkan dari tubuh penderita lewat tinja. Jika tinja jatuh ke tanah dan cuaca hangat, telur cacing akan menetas menjadi larva dalam waktu sekitar dua hari. Larva kemudian menjadi dewasa dalam seminggu, dan dapat bertahan untuk waktu yang lama jika kondisi mendukung. Gejala spesifik infeksi cacing tambang yaitu anemia dan keluhan terkait peradangan usus seperti mual, sakit perut, kembung dan diare.

\section{Cacing cambuk (Trichuris trichiura dan Trichinella spiralis)}

Cacing cambuk banyak ditemukan di daerah tropis, seperti di Indonesia. Daur hidup cacing cambuk mirip dengan daur hidup cacing gelang, hanya pada cacing cambuk tidak ada siklus paru, Jadi cacing langsung ke perut tanpa melewati paru-paru dan tenggorokan. Cacing ini tinggal di usus besar dan terkadang di usus buntu. Gejala yang timbul bisa berupa nyeri perut/ nyeri ulu hati, diare dengan mukus/ lendir kental dan licin, kotoran disertai sedikit darah, anemia ringan, kehilangan nafsu makan penurunan berat badan, terjadi prolaps rektum (penonjolan di daerah anus).

\section{Kesimpulan}

1. Ketersediaan sarana / fasilitas layanan kesehatan dan berbagai program ataupun layanan kesehatan bagi masyarakat di Dusun Manyuluh masih belum ada.

2. Anak-anak Dusun Manyuluh umumnya memiliki permasalahan dalam hal kecacingan dikarenakan minimnya pengetahuan tentang perilaku higienis ( Seperti MCK yang sehat, cara cuci tangan dengan sabun yang baik, sebelum makan dan sesudah BAB) sehingga mudah terinfeksi telur cacing yang infektif.

3. Kecacingan pada anak akan menyebabkan menurunnya kondisi kesehatan gizi, kecerdasan dan produktivitas penderitanya, sehingga secara ekonomi banyak menyebabkan kerugian serta mempengaruhi kualitas sumber daya manusia.

\section{Saran}

1. Mengadakan secara rutin penyuluhan guna meningkatkan kesadaran dan pengetahuan masyarakat tentang perilaku higienis.

2. Mengadakan pemeriksaan kesehatan rutin setiap 6 bulan sekali, baik pemeriksaan fisik maupun pemeriksaan tinja guna memantau angka kejadian kecacingan di Dusun Manyuluh 


\section{Daftar Pustaka}

1. www.depkes.go.id

2. Berkat, AP. Profil Lokasi Kegiatan Bio-Right. Persiapan Program Restorasi Ekosistem Kalimantan Tengah (PREKT). Palangka Raya: 2011

3. Suseno, Untung. Profil Kesehatan Indonesia 2008. Jakarta: Departemen Kesehatan Republik Indonesia. 2009

4. Rampengan, TH. Penyakit Infeksi Tropik pada Anak. Edisi 2. Jakarta: EGC. 2007

5. Nutrition Assessment in Community with Special Reference to Less Technically Develop Countries. Jelliffe DB. Oxford University Press. 1990.

6. Hay Jr. WW, Hayward AR, Levin MJ, Sondheimer JM. Current Pediatric Diagnosis \& Treatment 15th ed. Lange Medical Books / McGraw Hill, Singapore 2001: 1 - 274.

7. Behrman RE, Kliegmen RM, Jenson HB. Nelson Textbook of Pediatrics 17ed. Saunders, Philadelphia 2004 : 23 - 66 